\title{
A Meta Analysis of Materiality Studies
}

\author{
David E. Vance ${ }^{1}$ \\ ${ }^{1}$ Clinical Assistant Professor, School of Business Camden, Rutgers University, USA \\ Correspondence: David E. Vance, Clinical Assistant Professor, School of Business Camden, Rutgers University, \\ USA.
}

Received: November 29, 2021

Accepted: January 9, 2022

Online Published: January 11, 2022

doi:10.5430/afr.v11n1p1

URL: https://doi.org/10.5430/afr.v11n1p1

\begin{abstract}
The Supreme Court and the Public Company Accounting Oversite Board (PCAOB) has said that an amount is material if there is a substantial likelihood it will influence a reasonable investor's judgment. The American Institute of Certified Public Accountants (AICPA) has said that an amount is material if there is a substantial likelihood it will influence a reasonable user's judgment. The Financial Accounting Standards Board (FASB) has refused to define materiality. The Securities and Exchange Commission (SEC) has said that qualitative factors can make even small amounts material.

Reasonable implies a consensus of opinion. This article is a meta-analysis of 31,155 materiality decisions made by 335 cohorts in 48 studies with the objective of defining what is reasonable. A cohort is a group of like individuals faced with a common materiality decision. Materiality in this study is measured as a percentage of net income. The mean threshold of materiality is $7.84 \%$ and the median is $6.81 \%$. Both thresholds are substantially higher than the often-discussed threshold of 5.0\%. A quarter of the participants in these studies set the threshold of materiality at $11.90 \%$ and the threshold for a statistically significant difference from the consensus is $17.51 \%$.

Ultimately, materiality will be decided through civil and criminal litigation. Finders of fact, usually jurors, will be asked to determine what a reasonable investor would conclude. Few jurors have the training and experience of investors, so without context, they can only guess what a reasonable investor would conclude. This study provides that context.
\end{abstract}

Keywords: material, materiality, reasonable investor, securities litigation, finder of fact, juror

\section{Introduction}

Whether something is material is a much-debated issue. What gives rise to a materiality decision? Actions that could give rise to a materiality decision include a mistake, a failure to include or exclude something, or a math error. Failure to properly apply accounting principles such as accounting for leases or bond premium discounts can give rise to a materiality decision. Disputes between an auditor and company may arise regarding the classification of an expense, whether an asset is impaired and by how much, and whether accounting estimates must be adjusted. If an item is material, that fact might warrant disclosure, a restatement, or filing an SEC Form 8-K.

The concept of materiality can never be used to justify increasing revenue, gain, income or asset value by a small, but arbitrary, amount. Materiality can never be used to justify reducing an expense, loss or liability by a small, but arbitrary, amount.

The threshold of materiality has implications for auditors during both the planning and evaluation phase of the audit, for managers and board members, for creditors, investors and others. Ultimately, materiality will be decided through civil and criminal litigation. Finders of fact, usually jurors, will be asked to determine what a reasonable investor would conclude. Few jurors have the training and experience of investors, so without context, they can only guess what a reasonable investor would conclude. This study provides that context.

\section{Literature}

\subsection{Accounting Standards}

The Securities Exchange Act of 1934 (SEA 1934), §10(b) prohibits any untrue statement of a material fact, or the omission of a material fact, that would make statements misleading in connection with the sale of securities. What then is material? The AICPA's Statement on Auditing Standard SAS-138 (AICPA 2019a) defines materiality thus: 
"Misstatements, including omissions, are considered to be material if there is a substantial likelihood that, individually or in the aggregate, they would influence the judgment made by a reasonable user based on financial statements."

The AICPA in their Standards of Attestation (AICPA 2019b) says a practitioner may assume that intended users (a) have a reasonable knowledge of the subject matter, (b) understand appropriate levels of materiality, and (c) understand any inherent uncertainties involved in measuring or evaluating the subject matter.

The Public Company Accounting Oversight Board, (PCAOB 2010) cites two Supreme Court cases, TSC Industries v. Northway (1976) and Basic, Inc. v. Levinson, (1988) when defining materiality.

"The Supreme Court of the United States has held that a fact is material if there is a substantial likelihood that the... fact would have been viewed by the reasonable investor as having significantly altered the 'total mix' of information made available."

In formulating their test for materiality, the Supreme Court noted that, "Some information is of such dubious significance that insistence on its disclosure may accomplish more harm than good." They further state that if the standard of materiality is unnecessarily low, management might simply bury shareholders in an avalanche of trivial information to avoid litigation (TSC Industries $v$. Northway 1976).

In TSC Industries, the Supreme Court rejected the materiality formulation of the appeals court below (Northway $v$. TSC Industries 1975) which said that an item is material if a reasonable shareholder might consider an item important. It also rejected the holdings of appeals courts in Gerstle v. Gamble-Skogmo, Inc. (1973) and Smallwood v. Pearl Brewing Co. (1974) which held that an item is material if a reasonable man would attach importance to the fact misrepresented or omitted. Instead, the Supreme Court adopted the "substantial likelihood" test. The Financial Accounting Standards Board (FASB) takes the position that materiality is a legal issue that can be changed by legislation or the courts. Therefore, it declined to provide authoritative guidance (FASB 2015).

\subsection{SEC Standards SAB-99}

SEC Staff Accounting Bulletin 99 (SAB-99 1999) complicates the assessment of materiality by citing five "qualitative factors" which might cause small misstatements to reach the threshold of materiality including: (a) changing a loss into a profit, (b) masking a change in earnings or other trends, (c) hiding a failure to meet analysts' expectations, (d) affecting compliance with loan covenants or (e) impacting executive compensation. The SEC's fear is that companies will use the concept of materiality to manage earnings. There is a substantial body of literature on earnings management (Legoria 2012).

Courts have long recognized that materiality is not simply a numerical issue. Since courts have said there are no bright lines in assessing materiality, the issue might turn on management intent. A decision to buy or sell an asset, close a plant or run it overtime, to incur an expense or defer that expense might just be prudent management. In doing so, a company might legitimately consider an item immaterial and stumble across one of the qualitative factors in SAB-99. The securities law issue is whether this constitutes an attempt to make a prohibited misleading statement (SEA 1934).

Direct evidence of intent is rarely available. Given the difficulties of determining intent, it seems unrealistic to require, as does SAB-99, that regulators, auditors and others should be able to divine the intent of management in making materiality judgments (Zabel 2002).

An even greater problem with SAB-99 is that it invites jurors, as finders of fact, to speculate as to whether and under what circumstances the factors listed in SAB-99 would lead to a "substantial likelihood" that they would influence an investor's judgment.

One might argue it is simply common sense that changing a loss to a profit is material. But common sense is not evidence. Jurors cannot be asked to speculate on what constitutes a "substantial likelihood" that an item significantly alters the total mix of information without sufficient credible evidence.

\subsection{Evidential Standard}

Arguably, the SEC holds itself out as an expert in securities matters. The Federal Rules of Evidence says that expert testimony must be based on sufficient facts or data (FRE 2011 702(b)). Courts are the gatekeepers of admissibility. The admissibility of all expert testimony is governed by Federal Rules of Evidence (FRE 2011 104(a)) which says a proponent has the burden of establishing that pertinent admissibility requirements are met (Daubert v. Merrel Dow Pharmaceuticals, Inc. 1993; Bourjaily v. United States 1987). These evidentiary standards apply to both the SEC and private litigants. 
Is it enough for the SEC to argue that the tests listed in SAB-99 would influence someone's judgment? If SEC assertions about SAB-99 criterion for making an item material are not supported by facts or data in the form of credible studies, they are inadmissible as evidence.

As of this writing, no studies directly on point for the five SAB-99 criteria have been found. In considering studies to support SAB-99 it is important to differentiate between studies that purport to document earnings management and studies that document the circumstances in which such alleged earnings management is a substantial factor in influencing an investor's or user's judgment.

\subsection{Standards for the Finders of Fact}

The Supreme Court chose to use the term investor in determining materiality. It could have chosen to use the term someone, anyone or a reasonable person, but it did not. It said an item is material if there is a "substantial likelihood" that the... fact would have been viewed by the reasonable investor as having significantly altered the 'total mix' of information made available (TSC Industries v. Northway 1976; Basic, Inc. v. Levinson 1988).

Investors often have skill and learning that others do not, and may have a risk tolerance that others do not. This makes it difficult, though not impossible, for the ordinary juror to determine how a reasonable investor would assess information.

The AICPA says a fact is material if there is a "substantial likelihood" that it would influence the judgment made by a reasonable user (AICPA 2019a, AICPA 2019b). The AICPA Standards of Attestation (AICPA 2019b) says a practitioner may assume that intended users have a reasonable knowledge of the subject matter. Such an assumption cannot be made for a typical juror. A typical juror might not even be able to read a financial statement. That makes it difficult for jurors to assess whether an item constitutes a material change to a financial statement.

Given the distinction between an investor or user on the one hand and a typical juror on the other hand, it is important that jurors be given a broad context within which they can judge the facts.

\section{Methodology}

Materiality is measured in a number of ways. For example, Petroni (1996) measures materiality as a function of assets, Madden (1972) measures materiality in terms of sales, Kuene (2012) models materiality decisions as a function of audit fees, the number of analysts following a company and other qualitative factors, and Cho (2003) measures materiality as a function of the change in stock price. There are also a large number of studies that discuss materiality and risk but never quantify their findings (Shawver 2008; Popova 2018). This meta-analysis analyzes materiality as a function of net income.

Meta-analysis integrates data from a number of studies. Table 1 Source Material lists the 48 studies used in this meta-analysis. Data is not always reported the same way. Data must be standardized for analysis (Whitlock, 2005). Reasonable assumptions and estimates are made to convert source material findings to a standardized form. For example, where ranges are reported, the midpoint of those ranges are used. One study measured materiality in terms of Earnings per Share (EPS) (Rose 1970) and changes in EPS were used as a proxy for changes in net income. Interpretation of graphs was required for some studies (Messier 1983; Hofstedt 1977). Pretax income was converted to after tax income for other sources (DeZoort 2003; Nelson 2004; Wright 1997; Hofstedt 1977) using average corporate tax rates (Compustat 2006). One source reported materiality via regression analysis (Waters 1997). Other sources provided data in the form of frequency within ranges (Chewning 1998; Chewning 1989; Fesler 1989; Morris 1984). One source reported data from six interest groups (Pattillo 1975) and the number of individuals in the study, so data were apportioned to the groups as recommended by DeCoster (2004). The balance of the sources either explicitly provided materiality as a percentage of net income or provided information to compute it. 
Table 1. Source Material

A cohort, $\mathrm{C}$, is a group of like individuals faced with the same materiality decision. $\mathrm{M}$ is the number of materiality decisions in each study. Mthd is the study method. $\mathrm{H}$ indicates the study is based on analysis of historical evidence and $\mathrm{E}$ means the study was based on an experimental method such as a questionnaire or case study.

\begin{tabular}{|c|c|c|c|c|c|}
\hline Study & $\mathbf{C}$ & $\mathbf{M}$ & Participants Descriptions & Mthd & Issues \\
\hline Acito, 2009 & 4 & 244 & Auditors & $\mathrm{H}$ & Leases \\
\hline Baskin, 1972 & 1 & 69 & Investors \& analysts & $\mathrm{E}$ & Accounting principles \\
\hline Bates, 1982 & 3 & 67 & Auditors & $\mathrm{E}$ & Contingent liability \\
\hline Bernardi, 1996 & 9 & 152 & Auditors & $\mathrm{E}$ & Asset impairment \\
\hline Bernstein, 2021 & 1 & 1 & Auditor & $\mathrm{H}$ & Various \\
\hline Boatsman, 1974 & 2 & 990 & Auditors & $\mathrm{E}$ & Accounting principles \\
\hline Burgstahler, 2000 & 13 & 183 & Auditors & $\mathrm{E}$ & Accounting principles \\
\hline Chewning, 1989 & 7 & 284 & Auditors & $\mathrm{H}$ & Expense treatment \\
\hline Chewning, 1998 & 7 & 139 & Managers \& board members & $\mathrm{H}$ & Revenue or gain \\
\hline Christensen, 2020 & 1 & 120 & Investors & $\mathrm{E}$ & Investment \\
\hline Chung, 2021 & 20 & 4,332 & Auditors & $\mathrm{H}$ & Accounting estimate \\
\hline Costigan, 1995 & 1 & 351 & Auditors & $\mathrm{H}$ & Accounting principles \\
\hline Cumming, 1973 & 20 & 748 & Auditor \& mangers & $\mathrm{E} \& \mathrm{H}$ & Accounting principles \\
\hline DeZoort, 2003A & 1 & 55 & Managers \& board members & $\mathrm{E}$ & Asset impairment \\
\hline DeZoort, 2003B & 4 & 262 & Managers \& board members & $\mathrm{E}$ & Asset impairment \\
\hline DeZoort, 2006 & 8 & 160 & Auditors & $\mathrm{E}$ & Asset impairment \\
\hline Dyer, 1975 & 6 & 245 & Auditors & $\mathrm{E}$ & $\begin{array}{l}\text { Bond premiums, casualty } \\
\text { losses \& revenue or gain }\end{array}$ \\
\hline Estes 1988 & 1 & 596 & Auditors & $\mathrm{E}$ & Asset impairment \\
\hline Fesler, 1989 & 1 & 126 & Managers \& board members & $\mathrm{H}$ & Contingent liability \\
\hline Frishkoff-Stringer 1970 & 6 & 180 & Auditors & $\mathrm{H}$ & Expense treatment \\
\hline Hatfield, 2006 unpub. & 1 & 155 & Auditors & $\mathrm{E}$ & Asset impairment \\
\hline Hofstedt, 1977 & 1 & 19 & Professors \& students & $\mathrm{E}$ & Asset impairment \\
\hline Jennings, 1987A & 12 & 1,068 & Judges, attorneys \& auditors & $\mathrm{E}$ & $\begin{array}{l}\text { Asset impairment, bribes, } \\
\text { contingent liabilities, \& } \\
\text { revenue treatment }\end{array}$ \\
\hline Jennings, 1987B & 20 & 1,005 & $\begin{array}{l}\text { Bankers \& creditors, investors, } \\
\text { bankers, \& auditors }\end{array}$ & $\mathrm{E}$ & $\begin{array}{l}\text { Asset impairment, bribes, } \\
\text { contingent liabilities \& } \\
\text { revenue treatment }\end{array}$ \\
\hline Jennings, 1991 & 1 & 77 & Attorneys & $\mathrm{E}$ & Asset impairment \\
\hline Libby, 2005 & 4 & 61 & Auditors & $\mathrm{E}$ & Expense treatment \\
\hline Legoria 2012 & 4 & 11,829 & Auditors & $\mathrm{H}$ & Tax Adjustment \\
\hline Liu, 2002 & 6 & 437 & Managers \& board members & $\mathrm{H}$ & Expense treatment \\
\hline Messier, 1983 & 2 & 29 & Auditors & $\mathrm{E}$ & Accounting principles \\
\hline Moriarity, 1979 & 20 & 20 & Auditors & $\mathrm{E}$ & Accounting principles \\
\hline Moriarity, 1976 & 2 & 15 & Auditors & $\mathrm{E}$ & Expense treatment \\
\hline Morris, 1984 & 10 & 221 & Auditors & $\mathrm{H}$ & Expense treatment \\
\hline Morris, 1988 & 8 & 334 & Auditors & $\mathrm{H}$ & Expense treatment \\
\hline
\end{tabular}




\begin{tabular}{|c|c|c|c|c|c|}
\hline Nelson, 2004 & 8 & 1,840 & Auditors & $\mathrm{E}$ & $\begin{array}{l}\text { Asset impairment, } \\
\text { revenue or gain treatment }\end{array}$ \\
\hline Nelson, 2005 & 6 & 681 & Auditors & $\mathrm{E}$ & $\begin{array}{l}\text { Asset impairment, } \\
\text { revenue or gain treatment }\end{array}$ \\
\hline Newton, 1997 & 8 & 15 & Auditors & $\mathrm{E}$ & $\begin{array}{l}\text { Asset impairment, } \\
\text { contingent liability }\end{array}$ \\
\hline Pattillo, 1975 & 6 & 684 & $\begin{array}{l}\text { Auditors, investors, professors, } \\
\text { bankers, managers }\end{array}$ & $\mathrm{E}$ & Accounting principles \\
\hline Rose, 1970 & 4 & 121 & Professors \& students & $\mathrm{E}$ & Accounting principles \\
\hline Schneider, 1990 & 9 & 1,494 & Managers & $\mathrm{E}$ & $\begin{array}{l}\text { Asset impairment \& } \\
\text { expense treatment }\end{array}$ \\
\hline Shafer, 2002 & 2 & 70 & Managers & $\mathrm{E}$ & Revenue or gain treatment \\
\hline Tuttle, 2002 & 3 & 216 & Professors \& students & $\mathrm{E}$ & Accounting principles \\
\hline Waters, 1997 & 2 & 130 & Auditors & $\mathrm{H}$ & Accounting principles \\
\hline Wheeler, 1993 & 27 & 284 & Auditors & $\mathrm{H}$ & Accounting principles \\
\hline Woolsey, 1954A & 21 & 351 & $\begin{array}{l}\text { Auditors, investors, professors, } \\
\text { bankers, managers }\end{array}$ & $\mathrm{E}$ & $\begin{array}{l}\text { Bond premiums, casualty } \\
\text { losses \& revenue or gain }\end{array}$ \\
\hline Woolsey, 1954B & 21 & 158 & $\begin{array}{l}\text { Auditors, investors, professors, } \\
\text { bankers, managers }\end{array}$ & $\mathrm{E}$ & $\begin{array}{ll}\text { Asset } & \text { impairment, } \\
\text { contingent liability \& } \\
\text { leases }\end{array}$ \\
\hline Woolsey, 1973 & 5 & 176 & $\begin{array}{l}\text { Auditors, investors, professors, } \\
\text { bankers, managers }\end{array}$ & $\mathrm{E}$ & Expense treatment \\
\hline Wright, 1983 & 4 & 100 & Auditors & $\mathrm{E}$ & $\begin{array}{l}\text { Contingent liability \& } \\
\text { revenue }\end{array}$ \\
\hline Wright, 1997 & 2 & 261 & Auditors & $\mathrm{H}$ & Accounting principles \\
\hline Totals & 335 & 31,155 & & & \\
\hline
\end{tabular}

The threshold of materiality was computed as a weighted average across studies as shown in equation (1).

$$
M=\frac{\sum \mathrm{n}_{i} \times M_{i}}{\Sigma n_{i}}
$$

Where $\mathrm{M}$ is mean materiality, $\mathrm{n}_{\mathrm{i}}$ is the number of materiality decisions in cohort $\mathrm{i}$, and $\mathrm{M}_{\mathrm{i}}$ is the materiality of cohort i.

The standard deviation of materiality is given as equation (2).

$$
\left.\sigma \quad=\left(\Sigma\left(\mathrm{n}_{\mathrm{i}} \mathrm{X}\left(\mathrm{M}_{\mathrm{i}}-\mathrm{M}\right)^{2}\right) /\left(\left(\Sigma \mathrm{n}_{\mathrm{i}}\right)-1\right)\right)\right) \cdot .5
$$

Where $n_{i}$ is the number of materiality decisions in cohort $i, M_{i}$ is the materiality of cohort $i$, and $M$ is the overall mean materiality computed in equation (1).

\section{Findings}

The mean threshold of materiality is $7.84 \%$ and the median is $6.81 \%$ across 31,155 material decisions made by 335 cohorts as shown in Table 2 Descriptive Statistics. There is little difference between materiality measured in an experiment such as a case study or questionnaire and materiality measured by an analysis of historical decisions. This is surprising because there are no consequences in an experiment and potentially significant consequences in real-world decision making. 
Table 2. Descriptive Statistics

A cohort, $\mathrm{C}$, is a group of like individuals addressing the same materiality issue; $\mathrm{n}$ is the total number of materiality decisions made. The column $90^{\text {th }}$ is the threshold between the lower $90 \%$ of materiality decisions and the upper $10 \%$. The column * is the cutoff for statistical significance at the 0.1 level.

\begin{tabular}{llllllllll}
\hline & $\mathbf{C}$ & $\mathbf{n}$ & Mean & $\boldsymbol{\sigma}$ & $\mathbf{Q 1}$ & Median & Q3 & 90th & $*$ \\
\hline Overall & 335 & 31,155 & $7.84 \%$ & $5.86 \%$ & $3.62 \%$ & $6.81 \%$ & $11.90 \%$ & $15.00 \%$ & $17.51 \%$ \\
Experiments & 223 & 11,437 & $7.90 \%$ & $4.59 \%$ & $4.69 \%$ & $6.78 \%$ & $10.37 \%$ & $14.47 \%$ & $15.47 \%$ \\
Historical & 112 & 19,718 & $7.80 \%$ & $6.49 \%$ & $2.50 \%$ & $6.77 \%$ & $11.90 \%$ & $15.45 \%$ & $18.51 \%$ \\
Totals & $\mathbf{3 3 5}$ & $\mathbf{3 1 , 1 5 5}$ & & & & & & & \\
\hline
\end{tabular}

The mean threshold of materiality ranges from a low of 7.00\% for managers and board members to a high of $10.76 \%$ for bankers and creditors as shown in Table 3 Materiality by Interest Group. Logic might dictate that bankers and creditors would be more sensitive than managers and board members and their materiality thresholds would be lower. On the other hand, it could be that bankers and creditors have a more realistic and skeptical view of financial statements. The median threshold of materiality for bankers and creditors at $11.0 \%$ is also much higher than the median threshold for managers and board members at $6.73 \%$.

Table 3. Materiality by Interest Group

A cohort, $\mathrm{C}$, is a group of like individuals addressing the same materiality issue; $\mathrm{n}$ is the total number of materiality decisions made. The column $90^{\text {th }}$ is the threshold between the lower $90 \%$ of materiality decisions and the upper $10 \%$. The column $*$ is the cutoff for statistical significance at the 0.1 level.

\begin{tabular}{|c|c|c|c|c|c|c|c|c|c|c|}
\hline & & C & $\mathrm{n}$ & Mean & $\sigma$ & Q1 & Median & Q3 & 90th & $*$ \\
\hline Auditors & & 221 & 24,530 & $7.85 \%$ & $6.04 \%$ & $3.00 \%$ & $6.81 \%$ & $11.90 \%$ & $14.50 \%$ & $17.82 \%$ \\
\hline Bankers & $\&$ & & & & & & & & & \\
\hline Creditors & & 11 & 619 & $10.76 \%$ & $5.35 \%$ & $5.30 \%$ & $11.00 \%$ & $17.00 \%$ & $18.00 \%$ & $19.59 \%$ \\
\hline Investors & $\&$ & & & & & & & & & \\
\hline Analysts & & 28 & 1,124 & $8.01 \%$ & $5.06 \%$ & $4.00 \%$ & $4.90 \%$ & $12.00 \%$ & $14.46 \%$ & $16.36 \%$ \\
\hline Judges & $\&$ & & & & & & & & & \\
\hline Attorneys & & 9 & 661 & $7.66 \%$ & $3.78 \%$ & $4.00 \%$ & $8.60 \%$ & $11.00 \%$ & $13.00 \%$ & $13.90 \%$ \\
\hline Managers & $\&$ & & & & & & & & & \\
\hline Boards & & 50 & 3,599 & $7.00 \%$ & $5.37 \%$ & $3.32 \%$ & $6.73 \%$ & $8.01 \%$ & $17.60 \%$ & $15.86 \%$ \\
\hline Professors & $\&$ & & & & & & & & & \\
\hline Students & & 16 & 622 & $9.16 \%$ & $3.75 \%$ & $6.60 \%$ & $10.00 \%$ & $10.00 \%$ & $14.15 \%$ & $15.35 \%$ \\
\hline Totals & & 335 & 31,155 & & & & & & & \\
\hline
\end{tabular}

Differences in the threshold of materiality may seem small among interest groups when measured in terms of percentages. However, some of those differences are statistically significant as shown in Table 4 Perceptual Differences by Interest Group. The pooled standard deviation among interest groups was computed using equation (3).

$$
\sigma_{\mathrm{ij}}=\left(\sigma_{\mathrm{i}}^{2} / \mathrm{N}_{\mathrm{i}}+\sigma_{\mathrm{j}}^{2} / \mathrm{N}_{\mathrm{j}}\right) \cdot 5
$$

Where $\sigma_{\mathrm{ij}}$ is the pooled standard deviation, $\sigma_{\mathrm{i}}$ is the standard deviation of interest group $\mathrm{i}, \mathrm{N}_{\mathrm{i}}$ is the number of materiality decisions in interest group $i, \sigma_{j}$ is the standard deviation of interest group $j$, and $\mathrm{N}_{\mathrm{j}}$ is the number of materiality decisions in interest group $\mathrm{j}$.

Equation (4) was used to compute $Z$ values, where $X_{i}$ is the mean materiality of group i, $X_{j}$ is the mean materiality of group $\mathrm{j}$ and $\sigma_{\mathrm{ij}}$ is the pooled standard deviation.

$$
\mathrm{Z}=(\mathrm{Xi}-\mathrm{Xj}) / \sigma \mathrm{ij}
$$


Table 4. Perceptual Differences by Interest Group

Interest Groups are Auditors (A), Bankers \& Creditors (B), Investors \& Analysts (I), Judges \& Attorneys (J), Managers \& Board Members (M), and Professors \& Students (P). Z values are in the named columns Auditors, Bankers, etc. Statistical significance at the 0.1 level is denoted with an *, at the 0.05 level by ** and at the 0.01 level by $* * *$.

\begin{tabular}{lllllllllllll}
\hline & Auditors & $(\mathbf{A})$ & Bankers & $\mathbf{( B )}$ & Investors & $(\mathbf{I})$ & Judges & $(\mathbf{J})$ & Managers & (M) & Professors & (P) \\
\hline $\mathbf{A}$ & 0.00 & & 13.32 & $* * *$ & 1.03 & & -1.25 & & -8.72 & $* * *$ & 8.44 & $* * *$ \\
$\mathbf{B}$ & -13.32 & $* * *$ & 0.00 & & -10.47 & $* * *$ & -11.90 & $* * *$ & -16.14 & $* * *$ & -6.10 & $* * *$ \\
$\mathbf{I}$ & -1.03 & & 10.47 & $* * *$ & 0.00 & & -1.66 & $*$ & -5.76 & $* * *$ & 5.40 & $* * *$ \\
$\mathbf{J}$ & 1.25 & & 11.90 & $* * *$ & 1.66 & $*$ & 0.00 & & -3.83 & $* * *$ & 7.13 & $* * *$ \\
$\mathbf{M}$ & 8.72 & $* * *$ & 16.14 & $* * *$ & 5.76 & $* * *$ & 3.83 & $* * *$ & 0.00 & & 12.34 & $* * *$ \\
$\mathbf{P}$ & -8.44 & $* * *$ & 6.10 & $* * *$ & -5.40 & $* * *$ & -7.13 & $* * *$ & -12.34 & $* * *$ & 0.00 & \\
\hline
\end{tabular}

The mean threshold of materiality ranges from a low of $4.32 \%$ for bribery to a high of $13.52 \%$ for bond premium write-offs as shown in Table 5 Materiality by Issue. The median threshold of materiality is $3.00 \%$ for bribery and is $15.23 \%$ for bond premium write-offs. It could be that the threshold of materiality is influenced by the understandability of the issue. Bribery is always wrong, whereas a bond premium write-off seems more like a technical oversight.

Table 5. Materiality by Issue

A cohort, $\mathrm{C}$, is a group of like individuals addressing the same materiality issue; $\mathrm{n}$ is the total number of materiality decisions made. The column $90^{\text {th }}$ is the threshold between the lower $90 \%$ of materiality decisions and the upper $10 \%$. The column * is the cutoff for statistical significance at the 0.1 level.

\begin{tabular}{llllllllll}
\hline Issue & $\mathbf{C}$ & $\mathbf{n}$ & $\mathbf{M e a n}$ & $\mathbf{\sigma}$ & $\mathbf{Q 1}$ & Median & $\mathbf{Q 3}$ & $\mathbf{9 0 t h}$ & $*$ \\
\hline Accounting Principle & 109 & 4,416 & $8.94 \%$ & $6.82 \%$ & $4.00 \%$ & $6.20 \%$ & $10.72 \%$ & $17.06 \%$ & $20.19 \%$ \\
Accounting Estimate & 24 & 16,161 & $6.96 \%$ & $5.50 \%$ & $2.50 \%$ & $4.55 \%$ & $7.90 \%$ & $15.00 \%$ & $16.04 \%$ \\
Asset Impairment & 69 & 4,691 & $8.82 \%$ & $3.64 \%$ & $6.43 \%$ & $6.84 \%$ & $11.81 \%$ & $14.47 \%$ & $14.83 \%$ \\
Bond Premiums & 9 & 202 & $13.52 \%$ & $6.53 \%$ & $7.78 \%$ & $15.23 \%$ & $19.69 \%$ & $22.15 \%$ & $24.29 \%$ \\
Bribe & 7 & 468 & $4.32 \%$ & $2.15 \%$ & $3.00 \%$ & $3.00 \%$ & $6.00 \%$ & $9.00 \%$ & $7.87 \%$ \\
Contingent Liability & 22 & 752 & $11.74 \%$ & $8.04 \%$ & $4.86 \%$ & $10.00 \%$ & $18.56 \%$ & $21.66 \%$ & $25.01 \%$ \\
Expense & 50 & 2,178 & $7.87 \%$ & $8.34 \%$ & $1.47 \%$ & $4.80 \%$ & $7.53 \%$ & $20.00 \%$ & $21.63 \%$ \\
Leases & 12 & 325 & $11.42 \%$ & $6.98 \%$ & $6.30 \%$ & $13.10 \%$ & $18.92 \%$ & $19.38 \%$ & $22.94 \%$ \\
Revenue or Gain & 33 & 1,962 & $8.42 \%$ & $4.36 \%$ & $3.62 \%$ & $8.57 \%$ & $11.50 \%$ & $17.66 \%$ & $15.61 \%$ \\
Totals & $\mathbf{3 3 5}$ & $\mathbf{3 1 , 1 5 5}$ & & & & & & & \\
\hline S. Discuss & & & & & & & & &
\end{tabular}

\section{Discussion}

The AICPA has defined a fact as material if there is "a substantial likelihood" it would influence a reasonable user's judgment (AICPA 2019a, AICPA 2019b). The PCAOB and the Supreme Court define a fact as material if there is a "substantial likelihood" it would influence a reasonable investor's judgment (PCAOB 2010, TCS Industries v. Northway 1976). Arguably, there is a substantial difference between an investor and a user. Since investors have more at stake, it is reasonable to think they have more skill and learning than users. It is also likely they have a greater risk tolerance than users. The FASB has taken the position that materiality is a legal issue and has declined to define it. The AICPA, PCAOB and Supreme Court all reject a bright line test of materiality such as 3\% or 5\% in favor of a facts and circumstances test.

The SEC (SAB-99 1999) has listed five factors which might make even quantitatively small items material. Among them are items that (a) change a loss into a profit, (b) mask a change in earnings or other trends, (c) hide a failure to meet analysts' expectations, (d) affect compliance with loan covenants or (e) impact executive compensation. While these factors may be important in the limit, the SEC provides no evidence as to the circumstances in which each of 
these factors would have a "substantial likelihood" of influencing the judgment of either a reasonable user or investor.

At some point, the swing from losses to profits is significant enough to be material, but what is that point? If a company with ten billion in sales shows a loss of $\$ 0.01$ per share versus a profit of $\$ 0.01$ a share, does that meet the "substantial likelihood" test? Or are both numbers so close to zero that it makes no difference?

How much of a change in trend is necessary to trip the conditions of SAB-99? Is it the difference between a $2 \%$ growth rate and a $3 \%$ growth rate? Is it the difference between $10 \%$ and $11 \%$ ? Is it more or is it less? SAB-99 cites no studies that indicate the circumstances under which any of its five qualitative factors provide a "substantial likelihood" that they would influence an investor's judgment.

Whether something is material is a question of fact. Questions of fact are decided by jurors, not the SEC, courts or plaintiffs. Without a body of evidence to provide context, jurors are left to speculate about the nature of materiality and what SAB-99 factors mean. Worse, there is the risk that jurors might consider SAB-99 factors bright line tests in contravention of the Supreme Court's holding in TSC Industries v. Northway (1976).

Without studies to determine whether and when SAB-99 factors create a "substantial likelihood" of influencing a reasonable investor, SEC opinions fail to meet the test of admissibility set forth in Federal Rules of Evidence (FRE 2011 702(b), FRE 2011 104(a)). It is possible that the SEC will perform such studies in the future and it is possible that such studies will illuminate whether and when their five factors create a "substantial likelihood" that they will influence a reasonable investor's decision. Until then, the Federal Rules would seem to bar jurors from speculating as to their evidential weight. Future researchers could determine whether and under what circumstances the five factors in SAB-99 would influence a reasonable investor's judgment.

What then can the SEC, courts, juries and private litigants rely on? There is a large body of peer reviewed literature that provide context for what reasonable investors and users would have done in similar circumstances.

This study is a meta-analysis of 48 studies that measure 31,155 materiality decisions under a variety of circumstances as a function of net income. Participants in these studies had at least some of the skill and learning of users, if not that of investors. This data is the type of evidence contemplated by the Federal Rules of Evidence (FRE 2011 702(b), FRE 2011 104(a)).

While not setting a bright line threshold of materiality, this study provides jurors with context for reaching their own materiality decision. It is for a jury to decide whether a given item creates a "substantial likelihood." Perhaps a "substantial likelihood" only exists where there is a statistically significant difference between the consensus opinion as to materiality and the materiality decision which is the subject of given litigation. Again, this is a matter for the jury to decide.

\section{Conclusion}

An item is material if there is a "substantial likelihood" it would influence an investor's or a user's judgment. The courts and other authorities have rejected any bright line test of materiality. That leaves the materiality in any particular circumstance to the finders of fact, that is to jurors. Few jurors have the skill and learning of either investors or users of financial statements.

The SEC in SAB-99 has attempted to introduce de facto rules of thumb as to when an item is material. Those rules of thumb are not evidence. To date, the SEC has yet to cite studies on point as to when and under what circumstances those factors create a "substantial likelihood" of influencing an investor's or a user's judgment. Studies can become evidence upon which an expert opinion may be based. Until then, an argument can be made that the SEC's factors will only invite the jury to speculate as to whether SAB-99 criterion constitute a bright line test in contravention to TSC Industries v. Northway (1976).

Jurors, as finders of fact, must be provided with substantial credible evidence regarding what is reasonable in the context of materiality. Otherwise, they are left to speculate as to what a reasonable investor would do. This study provides context so that jurors can reach their own opinion based on a substantial body of evidence.

\section{References}

Acito, Andrew A., Jeffery J. Burks and W. Bruce Johnson. (2009). "Materiality Decisions and the Correction of Accounting Errors," The Accounting Review, May, 84(3), 659-688. https://doi.org/10.2308/accr.2009.84.3.659

Adams, Carol A., Pauline Weetman and Sidney J. Gray. (1993). Reconciling national with international accounting standards. European Accounting Review, Dec., 2(3), 471-494. https://doi.org/10.1080/09638189300000048 
AICPA. (2019a). Amendments to the Description of the Concept of Materiality. Statement on Auditing Standards. AU-C Section 320.02, Materiality in Planning and Performing an Audit: Materiality in the Context of an Audit

AICPA. (2019b). AICPA's Auditing Standards Board Issues New Standards to Amend the Description of the Concept of Materiality. Press Release AICPA.org. https://www.aicpa.org/press/pressreleases/2019/aicpa-asb-issues-new-standards-to-amend-the-description-of-the -concept-of-materiality.html

Basic, Inc. v. Levinson, 485 U.S. 224. (1988).

Baskin, Elba F. (1972). The Communicative Effectiveness of Consistency Exceptions. The Accounting Review, Jan, 38-51.

Bates, H. L., R.W. Ingram, \& P. M. J. Reckers. (1982). Auditor-Client Affiliation: The Impact on Materiality. Journal of Accountancy, April, 60-63.

Bernardi, R. A., \& K. V. Pincus. (1996). The relationship between materiality thresholds and judgments of fraud risk. Managerial Finance, 22(9), 1-15. https://doi.org/10.1108/eb018578

Bernstein, Albert. (2021). A Forensic Accountant's Take on Materiality. JD Supra Publisher, Sausalito, California. Feb. 21. https://www.jdsupra.com/legalnews/a-forensic-accountant-s-take-on-90638/

Boatsman, J. R., \& J. C. Robertson. (1974). Policy-Capturing on Selected Materiality Judgments. The Accounting Review, April, 342-352.

Bourjaily v. United States 483 U.S. 171. (1987). A proponent has the burden of establishing that pertinent admissibility requirements are met.

Burgstahler, David, Steven M. Glover and James Jiambalvo. (2000). Error Projection and Uncertainty in the Evaluation of Aggregate Error. Auditing: A Journal of Practice and Theory, 19(1), Spring, 79-99. https://doi.org/10.2308/aud.2000.19.1.79

Chewning, Eugene, G., Wheeler, Stephen W. and Chan, Kam C. (1998). Evidence on Auditor and Investor Materiality Thresholds Resulting from Equity for Debt Swaps. Auditing: A Journal of Practice and Theory, 17(1), Spring, 39-53.

Chewning, Gene, Kurt Pany and Stephen Wheeler. (1989). Auditor Reporting Decisions Involving Accounting Principle Changes: Some Evidence on Materiality Thresholds. Journal of Accounting Research, 27(1), Spring, 78-96. https://doi.org/10.2307/2491208

Cho, Seong-Yeon, Robert Hagerman, Sandeep Nabar, and Evelyn Patterson, Evelyn, R. (2003). Measuring Stockholder Materiality. Accounting Horizons Supplement, 63-76. https://doi.org/10.2308/acch.2003.17.s-1.63

Christensen, Brant, Aasumund Eilifsen, Steven Glover and William Messier Jr. (2020). The Effect of Audit Materiality Disclosures on Investor's Decision Making. Accounting Organizations and Society, 87(101168), 1-13. https://doi.org/10.1016/j.aos.2020.101168

Chung, Phillip, Daniel Paik, Collin Rabe \& Marshall Geiger. (2021). Materiality Thresholds: Empirical Evidence from Change in Accounting Estimate Disclosures. Accounting Horizons, 35(3), 113-141. https://doi.org/10.2308/HORIZONS-19-114

Compustat Database. (2006). Data provided by Standard \& Poor's Compustat, a Division of The McGraw-Hill Companies, Inc.

Costigan, M. L., \& D. T. Simon. (1995). Auditor materiality judgment and consistency modifications: Further evidence from SFAS No. 96. Advances in Accounting, 13, 207-222.

Cumming, John. (1973). An Empirical Evaluation of Possible Explanations for the Differing Treatment of Apparently Similar Unusual Events. Journal of Accounting Research, Supplement, 11(3), 60-95. https://doi.org/10.2307/2490028

Daubert v. Merrel Dow Pharmaceuticals, Inc. 509 U.S. 579. (1993). A proponent has the burden of establishing that pertinent admissibility requirements are met

DeCoster, Jamie. (2004). "Meta-Analysis Notes," Department of Psychology, University of Alabama, Tuscaloosa. downloaded 12/31/2006 www.stat-help.com/notes.html

DeZoort A, Todd F., Dana R. Hermanson and Richard W. Houston. (2003a). Audit Committee Support for Auditors: 
The Effects of Materiality Justification and Accounting Precision. Journal of Accounting and Public Policy, 22(2), March-April, 175-199. https://doi.org/10.1016/S0278-4254(03)00007-3

DeZoort B, Todd F., Dana R. Hermanson and Richard W. Houston. (2003b). Audit Committee Member Support for Proposed Audit Adjustments: A Source Credibility Perspective. Auditing: A Journal of Theory and Practice, 22 (2), Sept., 189-205. https://doi.org/10.2308/aud.2003.22.2.189

DeZoort, Todd, Paul Harrison and Mark Taylor. (2006). Accountability and Auditor' Materiality Judgments: The Effects of Differential Pressure Strength on Conservatism, Variability and Effort. Accounting, Organizations and Society, 31(4-5), July-August, 373-390. https://doi.org/10.1016/j.aos.2005.09.001

Dyer, Jack L. (1975). Toward the Development of Objective Materiality Norms. The Arthur Andersen Chronicle, Oct., 38-49.

Estes, R., \& DD. Reames. (1988). Effects of Personal Characteristics on Materiality Decisions: A Multivariate Analysis. Accounting and Business Research, Autumn, 291-296. https://doi.org/10.1080/00014788.1988.9729376

FASB. (2015). Notes to Financial Statements (Topic 235), Sec. 235-10-50-7 \& 8 Materiality. Proposed Accounting Standards Update to FASB Accounting Standards Codification. Financial Accounting Standards Board. Norwalk, CT. Iss. Sept. 24.

Fesler, R. D., \& J. L. Hagler. (1989). Litigation disclosures under SFAS No. 5: A study of actual cases. Accounting Horizons, 3(1), 10-21.

FRE. (2011). Rule 104(a). Preliminary Questions. Federal Rules of Evidence. Dec. 1. The court must decide whether a witness is qualified.

FRE. (2011). Rule 702(b). Testimony by Expert Witnesses. Federal Rules of Evidence. Dec. 1. A witness who is qualified as an expert by knowledge, skill, experience, training, or education may testify in the form of an opinion or otherwise if... (b) the testimony is based on sufficient facts or data.

Frishkoff, P. (1970). An Empirical Investigation of the Concept of Materiality in Accounting. Empirical Research in Accounting, 116-129. https://doi.org/10.2307/2674697

Gerstle v. Gamble-Skogmo, Inc., 478 F.2d 1281, 1301-1302. (CA2 1973). ...a reasonable man would attach importance...

Hatfield, Richard C., Scott B. Jackson and Scott D. Vandervelde. (2006). The Effects of Auditor Rotation and Client Pressure on Proposed Audit Adjustments. Feb. unpublished working paper. Corresponding author S. B. Jackson, University of South Carolina, Columbia, SC. scott.jackson@moore.sc.edu.

Hofstedt, T. R., \& G. D. Hughes. (1977). An Experimental Study of the Judgment Element in Disclosure Decisions. The Accounting Review, 52(2), April, 379-395.

Jennings, M., D. C. Kneer, \& P. M. J. Reckers. (1987). A Re-examination of the Court of Materiality: Views of Auditors, Users and Officers of the Court. Studies A and B Auditing: A Journal of Practice and Theory, Spring, 104-115.

Jennings, Marianne M., Dan C. Kneer and Philip M. J. Reckers. (1991). Selected Auditor Communications and Perceptions of Legal Liability. Contemporary Accounting Research, 7(2), 449-465. https://doi.org/10.1111/j.1911-3846.1991.tb00824.x

Jennings, Marianne, M., Phillip M. J. Reckers, \& Daniel C. Kneer. (1991). The Auditor's Dilemma: The Incongruous Judicial Notions of the Auditing Profession and Actual Auditor Practice. American Law Business Journal, 99-125. https://doi.org/10.1111/j.1744-1714.1991.tb00630.x

Kuene, Marsha and Karla Johnstone. (2012). Materiality Judgments and the Resolution of Detected Misstatements: The Role of Managers, Auditors and Audit Committees. The Accounting Review, Sept, 87(5), 1641-1677. https://doi.org/10.2308/accr-50185

Legoria, Joseph, Kevin D. Melendrez and J. Kenneth Reynolds. (2012). Qualitative Audit Materiality and Earnings Management. Review of Accounting Studies, 18, 414-442, Dec. 22. https://doi.org/10.1007/s11142-012-9218-3

Libby, Robert, Mark W. Nelson \& James E. Hunton. (2005). Recognition v. Disclosure and Auditor Misstatement Correction: The cases of Stock Compensation and Leases. Social Sciences Research Network. Working paper series March 23, updated July 31. https://doi.org/10.2139/ssrn.692864 
Liu, C. S., \& H. F. Mittelstaedt. (2002). Materiality judgments and disclosure of retiree health care costs under SFAS No. 81. Review of Accounting Studies, 7, 405-434. https://doi.org/10.1023/A:1020711628299

Madden, Donald, Levis McCullers and Raymond van Daniker. (1972). The Materiality of Research and Development Expenditures. Journal of Accounting Research, 10(2), Autumn, 417-420. https://doi.org/10.2307/2490021

Messier, W. F., Jr. (1983). The Effect of Firm Type and Experience on Materiality/Disclosure Judgments. Journal of Accounting Research, Autumn, 320-341. https://doi.org/10.2307/2490795

Moriarity, S., \& Barron, F. H. (1979). A Judgment Based Definition of Materiality. Journal of Accounting Research, 17, Supplement, 114-136. https://doi.org/10.2307/2490615

Moriarity, S., \& F. Barron. (1976). Modeling the Materiality Judgments of Audit Partners. Journal of Accounting Research, 14(2), Autumn, 320-341. https://doi.org/10.2307/2490546

Morris, M. H., \& W. D. Nichols. (1988). Consistency Exceptions: Materiality Judgments and Audit Firm Structure. The Accounting Review, April, 237-254.

Morris, M. H., Nichols, W. D., \& Pattillo, J. W. (1984). Capitalization of Interest, Materiality Judgment Divergence and Users' Information Needs. Journal of Business Finance and Accounting, 11(4), Winter, 547-555. https://doi.org/10.1111/j.1468-5957.1984.tb00769.x

Nelson, Mark W., Steven D. Smith \& Zoe-Vonna Palmrose. (2004). Quantitative Materiality Perspectives and Auditors' Disposition of Detected Misstatements. Social Sciences Research Network Electronic Paper Collection, Jan. 29. https://doi.org/10.2139/ssrn.503662

Nelson, Mark W., Steven D. Smith and Zoe-Vonna Palmrose. (2005). The Effect of Quantitative Materiality Approach on Auditor's Adjustment Decisions. The Accounting Review, 80(3). 897-920. https://doi.org/10.2308/accr.2005.80.3.897

Newton, Lauren K. (1977). The Risk Factor in Materiality Decisions. The Accounting Review, LII(1), Jan., 97-108.

Northway, Inc. v. TSC Industries, Inc. 512 F.2d 330. (1975). ...a reasonable shareholder might consider an item important.

Pattillo, James W. (1975). Materiality: The (Formerly) Elusive Standard. The Financial Executive, August, 20-27.

PCAOB. (2010). AS 2105: Consideration of Materiality in Planning and Performing an Audit. General Auditing Standards. Public Company Accounting Oversight Board. AS2015:02. Dec. 15. https://pcaobus.org/oversight/standards/auditing-standards/details/AS2105

Petroni, Kathy and Mark Beasley. (1996). Errors in Accounting Estimates and Their Relation to Audit Firm Type. Journal of Accounting Research, 34(1), Spring, 151-171. https://doi.org/10.2307/2491337

Popova, Velina K. (2018). Integration of Fraud Risk in the Risk of Material Misstatement and the Effect on Auditors' Planning. Journal of Forensic Accounting, 3(1), A52-A79. https://doi.org/10.2308/jfar-52228

Rose, J., W. Beaver, S. Becker and G. Sorter. (1970). Toward and Empirical Measure of Materiality. Empirical Research in Accounting Selected Studies. Supplement of Journal of Accounting Research, 138-48. https://doi.org/10.2307/2674700

SAB-99. (1999). SEC Staff Accounting Bulletin: No. 99 - Materiality. Securities and Exchange Commission. 17 CFR Part 211, Staff Accounting Bulletin No. 99. Aug. 12. https://www.sec.gov/interps/account/sab99.htm

Schneider, Arnold and Neil Wilner. (1990). A Test of Audit Deterrent to Financial Reporting Irregularities Using Randomized Response Technique. The Accounting Review, July, 68-681.

SEA. (1934). Securities Exchange Act of 1934. (June 6, 1934, ch. 404, title I, § 1, 48 Stat. 881.) 15 US Code $\S 78$ a.

Shafer, William E. (2002). Effects of Materiality, Risk, and Ethical Perceptions on Fraudulent Reporting by Financial Executives. Journal of Business Ethics, July, 243-262. http://dx.doi.org/10.1023/A:1016049022458

Shawver, Tara. (2008). What Accounting Students Think About Whistleblowing. Management Accounting Quarterly, 9(4), Summer.

Smallwood v. Pearl Brewing Co., 489 F.2d 579, 603-604. (CA5 1974)....a reasonable man would attach importance... 
Stringer, Kenneth W. (1970). Discussion of an Empirical Investigation of the Concept of Materiality in Accounting. Journal of Accounting Research, 8. Empirical Research in Accounting: Selected Studies, 133-137. https://doi.org/10.2307/2674699

TSC Industries v. Northway, Inc., 426 U.S. 438, $449 . \quad$ (1976). June $14.449-450$. https://doi.org/10.1016/0041-0101(76)90061-1

Tuttle, Brad, Maribeth Coller and R. David Plumlee. (2002). The Effect of Misstatements on Decisions of Financial Statement Users: An Experimental Investigation of Auditor Materiality Thresholds. Auditing: A Journal of Practice \& Theory, 21(1), March, 11-27. https://doi.org/10.2308/aud.2002.21.1.11

Waters II, John M., \& Mikel G. Tiller. (1997). Auditors' Materiality Thresholds: Some Empirical Findings Based on Real Data. American Business Review, 15(2), Jun., 115-119.

Wheeler, Stephen, Kurt Pany and Eugene Chewning. (1993). Inter-Firm Differences in Propensities to Modify Audit Opinions for Pre-SAS No. 58 Accounting Principles Change. Accounting Horizons, 7(3), Sept., 46-54.

Whitlock, Michael and Dolph Schluster. (2005). The Analysis of Biological Data, Part 5 Modern Statistical Methods. University of British Columbia ttp://jackalope.zoology.ubc.ca/ whitlock/ABD/WhiSchPart5.pdf

Woolsey, S. M. (1973). Materiality Survey. Journal of Accountancy, Sept., 91-92.

Woolsey, Samuel M. (1954a). Judging Materiality in Determining Requirements for Full Disclosure. Journal of Accountancy, Dec., 745-750.

Woolsey, Samuel M. (1954b). Development of Criteria to Guide the Accountant in Judging Materiality. Journal of Accountancy, Feb., 167-173.

Wright, Arnold and Sally Wright. (1997). Factors Affecting the Decision to Waive Audit Adjustments. Journal of Accounting, Auditing \& Finance, 12(1), Winter, 15-36, 22p. https://doi.org/10.1177/0148558X9701200102

Wright, Arnold. (1983). The Impact of CPA-Firm Size on Auditor Disclosure Preferences. The Accounting Review, LVIII(53), July, 621-632.

Zabel, Richard and James Benjamin, Jr. (2002). Reviewing Materiality in Accounting Fraud. New York Law Journal. Jan. 15.

\section{Copyrights}

Copyright for this article is retained by the author(s), with first publication rights granted to the journal.

This is an open-access article distributed under the terms and conditions of the Creative Commons Attribution license (http://creativecommons.org/licenses/by/4.0/). 